\title{
Pilot Study of Ultrafiltration-Nanofiltration Process for the Treatment of Raw Water from Huangpu River in China
}

\author{
Jianping ZHOU ${ }^{1,2}$, Naiyun GAO ${ }^{1}$, Guangyong PENG ${ }^{1,2}$, Yang DENG ${ }^{3}$ \\ ${ }^{1}$ State Key Laboratory of Pollution Control and Resource Reuse, Tongji University, Shanghai, China \\ ${ }^{2}$ Shanghai Municipal Engineering Design General Institute, Shanghai, China \\ ${ }^{3}$ Department of Civil Engineering and Surveying University of Puerto Rico Mayaguez, PR United States \\ Received April 14, 2009; revised June 15, 2009; accepted June 30, 2009
}

\begin{abstract}
Pilot-scale test was carried out to evaluate the performance of a combined ultrafiltration (UF)-nanofiltration (NF) membrane process for the treatment of raw water from Huangpu River, Shanghai, in China. Results showed that UF could significantly remove turbidity, iron and manganese, and also could retain a part of high molecular weight (MW) organic compounds. Subsequently, NF could further reject low MW organics and inorganic salts, and ensured the treated water to reach the Standards for Drinking Water Quality in China. It seemed that $90 \mathrm{~L} / \mathrm{m}^{2} \cdot \mathrm{h}$ was an appropriate permeate flux for UF system when the raw water was directly filtered by UF membrane, the addition of coagulant (alum or ferric chloride) was not preferable to mitigate the fouling of the UF membrane. After near 120 days operation, the permeate flux of NF could be maintained at $24-25 \mathrm{~L} / \mathrm{m}^{2} \cdot \mathrm{h}$ steadily, and no chemical clean was required.
\end{abstract}

Keywords: Ultrafiltration, Nanofiltration, Permeate Flux, Fouling

\section{Introduction}

As the main drinking water source of Shanghai, the largest city in China, the Huangpu River provides $4 \times 10^{6} \mathrm{~m}^{3}$ raw water every day to the city (accounting for $70 \%$ of its total daily water demand). Due to the increasing industrial pollution, the raw water quality of Huangpu River has been deteriorated in recent years. However, most of local water plants are employing conventional surface water treatment processes, which consist of coagulation, flocculation, sedimentation, rapid sand filtration and disinfection. These processes focus primarily on the removal of turbidity, colloid and pathogens, but are typically ineffective in reduction of dissolved organic pollutants, which may produce adverse impacts to human health (e.g. formation of disinfection byproducts during chlorination). Consequently, the finished water produced by these plants is difficult to completely comply with the Standards for Drinking Water Quality of China(GB57492006). To provide safe and clean drinking water, reliable and effective alternatives for conventional treatment processes are highly required.

Membrane processes, which are considered as innova- tive water treatment technologies, are gaining more and more attention due to their advantages compared with conventional processes, such as low chemical dosage, high separating efficiency, particularly in their effectiveness in the control of micropollutants in drinking water [1-3]. In this study, a combined UF-NF process was used to evaluate the performance on the treatment of raw water from Huangpu River.

\section{Materials and Methods}

\subsection{Experimental Set- up}

The pilot scale set-up was installed in the intake pump station of the Minhang Second Waterplant, Shanghai, China, with a designed flow rate at $3-5 \mathrm{~m}^{3} / \mathrm{h}$ (shown in Figure 1).

A laminated filter was installed before the UF booster pump to remove the particles with the diameter larger than $150 \mu \mathrm{m}$. The UF membrane(LH3, Lisheng Company, China), in-pressure hollow-fiber type, was made of PVC alloy, the effective filtration area of the membrane was $40 \mathrm{~m}^{2}$, and the molecular weight cut-off (MWCO) was 100,000 Dalton(Da). The UF system operated at a 


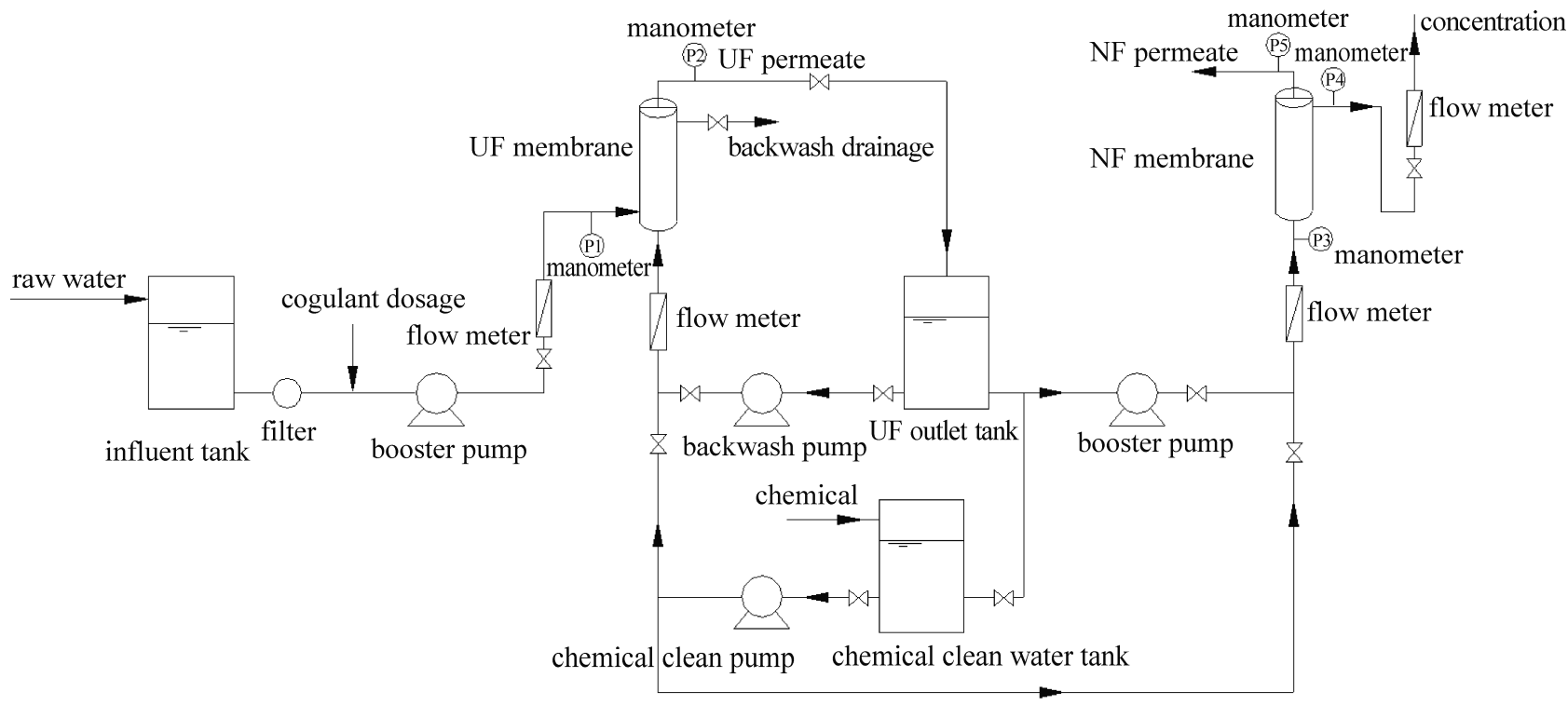

Figure 1. Schematic diagram of experiment set-up.

Table 1. Raw water quality statistics of Huangpu River(Songpu Bridge-Minhang section, 2003-2005).

\begin{tabular}{|c|c|c|c|c|c|c|}
\hline \multirow{2}{*}{ quality parameters } & \multicolumn{2}{|c|}{2003} & \multicolumn{2}{|c|}{2004} & \multicolumn{2}{|c|}{2005} \\
\hline & range & average & range & average & range & average \\
\hline Temperature $/{ }^{\circ} \mathrm{C}$ & $2.5 \sim 32.5$ & 17.7 & $3.5 \sim 31.5$ & 18.8 & $4.5 \sim 30.0$ & 19.5 \\
\hline Turbidity/NTU & $15 \sim 113$ & 44 & $19 \sim 150$ & 52 & $18 \sim 135$ & 44 \\
\hline $\mathrm{pH}$ & $6.9 \sim 7.8$ & 7.40 & $7.0 \sim 7.9$ & 7.44 & $7.0 \sim 7.9$ & 7.49 \\
\hline Ammonia/mg/L & $0.05 \sim 1.70$ & 0.65 & $0.05 \sim 3.00$ & 1.13 & $0.06 \sim 3.30$ & 1.03 \\
\hline Nitrite $/ \mathrm{mg} / \mathrm{L}$ & $0.01 \sim 0.33$ & 0.102 & $0.016 \sim 0.5$ & 0.136 & $0.01 \sim 0.39$ & 0.143 \\
\hline $\mathrm{COD}_{\mathrm{Mn}} / \mathrm{mg} / \mathrm{L}$ & $4.40 \sim 6.80$ & 5.68 & $4.50 \sim 7.30$ & 5.98 & $4.90 \sim 8.30$ & 6.05 \\
\hline Dissolve oxygen $(\mathrm{mg} / \mathrm{L})$ & $0.6 \sim 10.6$ & 4.8 & $0.4 \sim 9.6$ & 4.74 & $0.8 \sim 11.5$ & 4.76 \\
\hline iron $/ \mathrm{mg} / \mathrm{L}$ & $0.25 \sim 2.40$ & 1.08 & $0.27 \sim 5.00$ & 1.70 & $0.75 \sim 5.50$ & 1.95 \\
\hline manganese/mg/L & $0.07 \sim 0.39$ & 0.16 & 0.050 .43 & 0.18 & 0.050 .72 & 0.19 \\
\hline
\end{tabular}

dead-end filtration mode, and the backwash cycle was set at 30 minute. Once the operating pressure of the UF membrane $\left(\Delta \mathrm{P}=\mathrm{P}_{1}-\mathrm{P}_{2}\right)$ went up to near $0.1 \mathrm{MPa}$, a chemical clean would be executed to restore the membrane flux.

NF system was composed of 10 set of NF90-4040 (Dow Company), the total effective filtration area was $76 \mathrm{~m}^{2}$, the membrane was made of aromatic polyamide and polypiperazine, and the MWCO of NF was 200-300 $\mathrm{Da}$. The NF system operated at a cross-flow mode, and the recovery rate was set at $50 \%$.

\subsection{Quality of Raw Water}

The raw water quality of Huangpu River (Songpu Bridge-Minhang section, 2003 2005) was shown in Table 1, the main pollutants in the raw water were ammonia, $\mathrm{COD}_{\mathrm{Mn}}$, iron and manganese, which all exceed the standard required by Environmental Quality Standards for Surface Water (GB3838-2002,China)

\subsection{Analytical Methods}

The operating pressure of the membranes was calculated every hour by the record from the manometers. The in- 
fluent and effluent of UF and NF were collected once every 2 or 3 days, all samples were stored in the refrigerator at $4^{\circ} \mathrm{C}$ and were analyzed within $24 \mathrm{~h}$. Turbidity was measured by a turbidity meter $(2100 \mathrm{~N}, \mathrm{HACH})$. $\mathrm{UV}_{254}$ was measured by a spectrophotometer (UV Spectrumlab 52, Lingguang Co.) after the samples were filtered by $0.45 \mu \mathrm{m}$ membranes. The molecular weight (MW) distribution of organics was determined using the UF fractionation method [4]. TOC was measured by TOC analyzer (TOC-5000A, Shimadzu). Assimilable organic carbon (AOC) measurement was carried out using a method modified by Liu etal. [5], which was developed based on the procedures of Van der Kooij et al. [6]. And the other parameters were tested according to GB/T5750- 2006 (China).

\section{Results and Discussion}

\subsection{Removal of Turbidity by UF-NF System}

The removal of turbidity by UF-NF system was shown in Figure 2, Although the turbidity of raw water varied broadly within 19-83 NTU, UF could achieve a rejection of $99 \%$ and assure $0.1-0.2 \mathrm{NTU}$ in effluent, NF could further reduce the turbidity to less than $0.1 \mathrm{NTU}$ and increased the overall removal to $99.8 \%$.

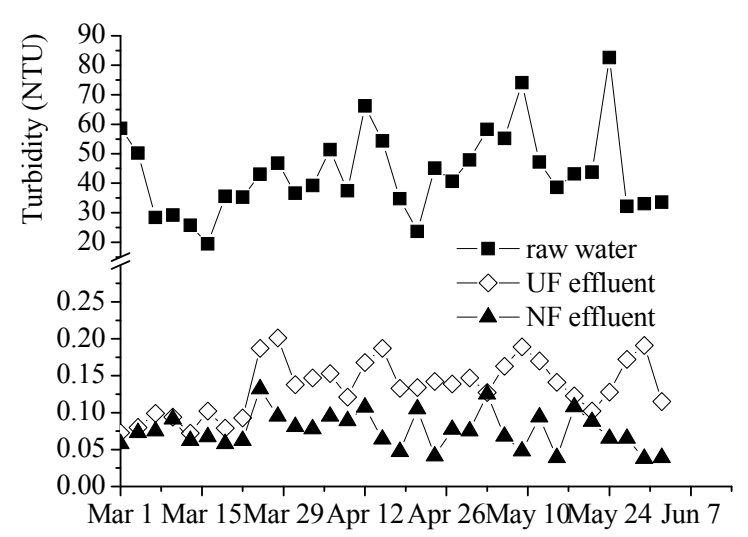

Figure 2. Turbidity removal by UF-NF system.

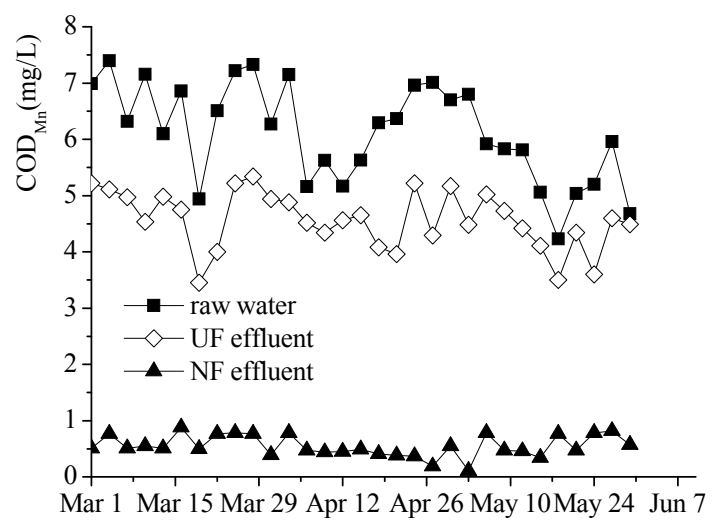

Figure 3. $\mathrm{COD}_{\mathrm{Mn}}$ removal by UF-NF system.

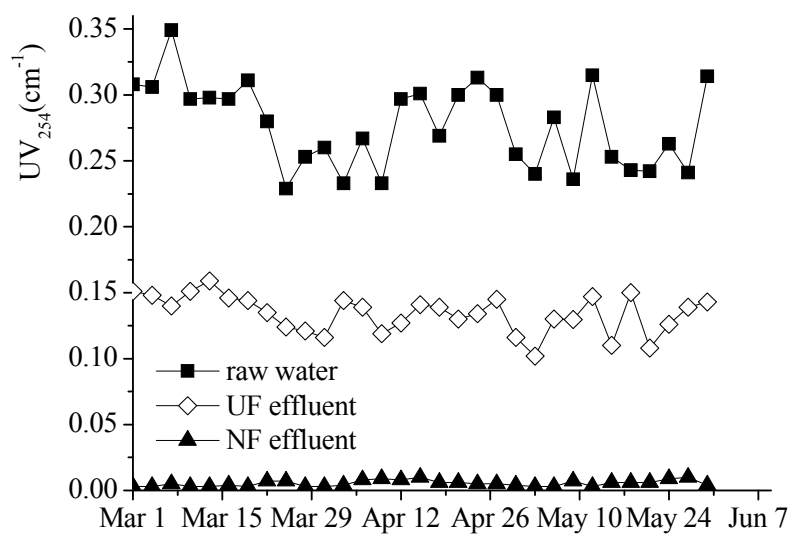

Figure 4. UV $_{254}$ removal by UF-NF system.

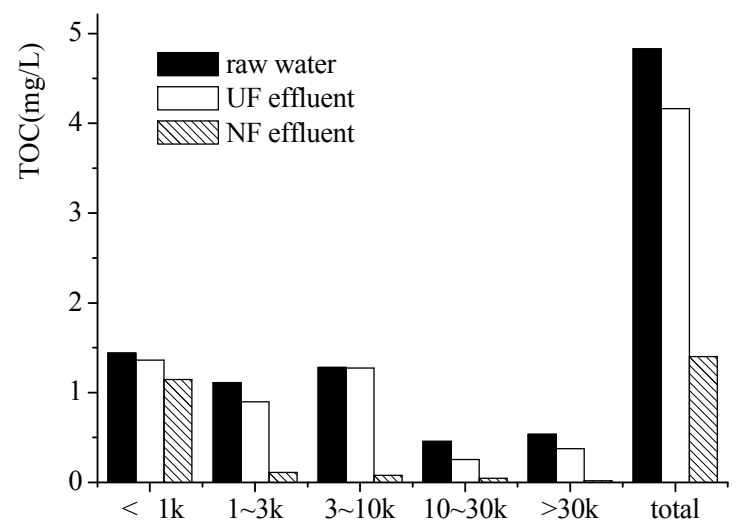

Figure 5. MW Distribution of Organics in Raw Water, UF Effluent and NF Effluent

\section{2. $\mathrm{COD}_{\mathrm{Mn}}$ and $U V_{254}$ Removal by UF-NF System}

Figure 3 and 4 showed $\mathrm{COD}_{\mathrm{Mn}}$ and $\mathrm{UV}_{254}$ removal by $\mathrm{UF}-\mathrm{NF}$ system. $\mathrm{COD}_{\mathrm{Mn}}$ of the raw water varied within 4.2-7.4 $\mathrm{mg} / \mathrm{L}$, and could be reduced to $3.5-5.4 \mathrm{mg} / \mathrm{L}$ by UF membrane, with a removing efficiency of $4.1 \%$ $38.8 \%$ (averaged at $25.6 \%$ ). NF membrane could reduce $\mathrm{COD}_{\mathrm{Mn}}$ to less than $1 \mathrm{mg} / \mathrm{L}$ and increase the removing efficiency to higher than $85 \%$.

$\mathrm{UV}_{254}$ is another surrogate measurement for the concentration of organic matters, particularly stands for the complex multiaromatic and multiconjugated humic substances in water. The overall removing efficiencies of $\mathrm{UV}_{254}$ achieved by UF and NF were 38.1\%-59.8\% (averaged at $48.2 \%$ ) and higher than $95 \%$, respectively.

To better understand the characteristics of the two membranes in rejection of organic matters, the MW distribution of dissolved organic compounds of raw water, UF effluent and NF effluent were analyzed, and the results were shown in Figure 5.

In the raw water, organics with $\mathrm{MW}>10 \mathrm{kDa}, 1-10$ $\mathrm{kDa}$ and $<1 \mathrm{kDa}$ were accounted for $21 \%, 59 \%$ and $30 \%$, respectively. UF mainly removed high MW organics, but 
showed poor rejection to the low MW organics, and the total TOC rejection of UF was only $14 \%$, which implied that UF alone could not provide satisfactory drinking water. NF could reject most of organics with $\mathrm{MW}>1 \mathrm{kDa}$ and increase the total TOC rejection to $72 \%$, and TOC of $\mathrm{NF}$ effluent could be reduced to less than $2 \mathrm{mg} / \mathrm{L}$.

\subsection{Ammonia Removal by UF-NF System}

Ammonia removal by UF-NF system (shown in Figure 6) was similar to the removal of $\mathrm{COD}_{\mathrm{Mn}}$ and $\mathrm{UV}_{254}$. Ammonia in the raw water are mostly composed of low MW organics (e.g. humic acid and fulvic acid), so it is difficult to be removed by UF, but could be rejected by NF effectively.

\subsection{AOC Removal by UF-NF System}

$\mathrm{AOC}$ is a parameter indicating the bacterial stability of water [5,7], high AOC always means high possibility of bacterial regrowth in water distribution system. N. Park et al found that AOC could significantly removed by NF membrane [8].

AOC of raw water, UF effluent, and NF effluent were shown in Figure 7. UF and NF could reduce AOC from

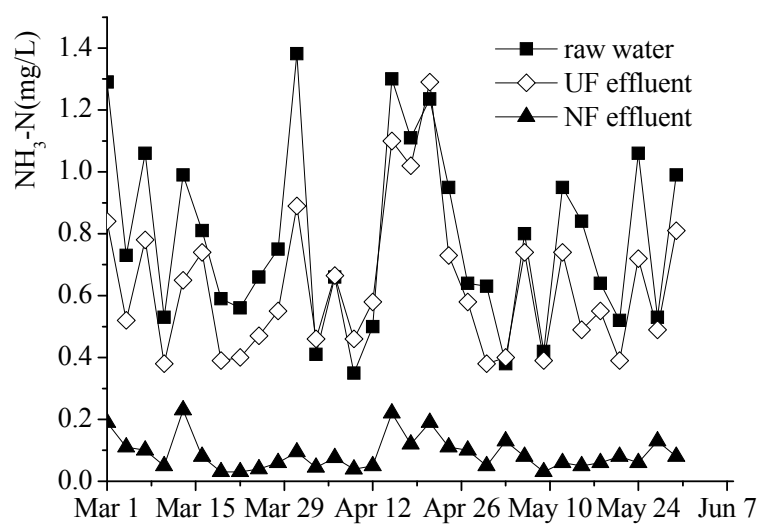

Figure 6. Ammonia removal by UF-NF system.

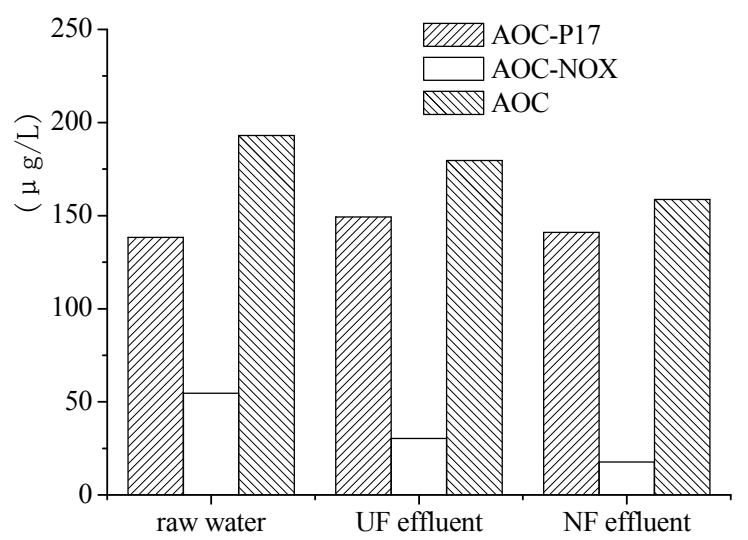

Figure 7. AOC removal by UF-NF system.

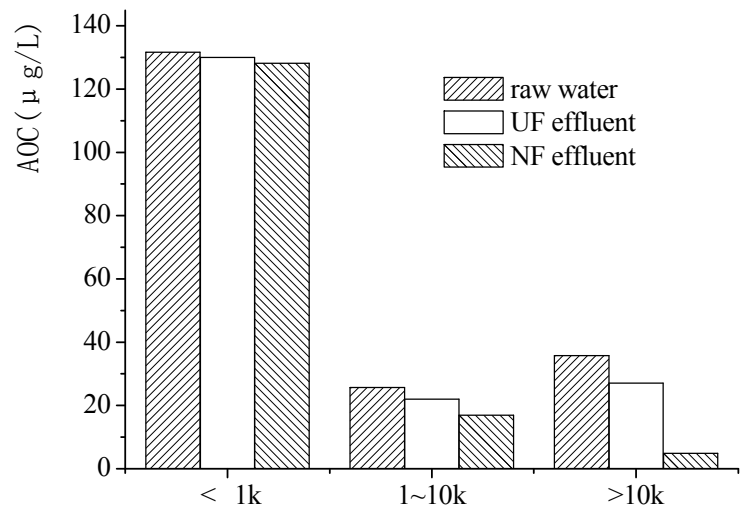

Figure 8. AOC distribution in different MW ranges.

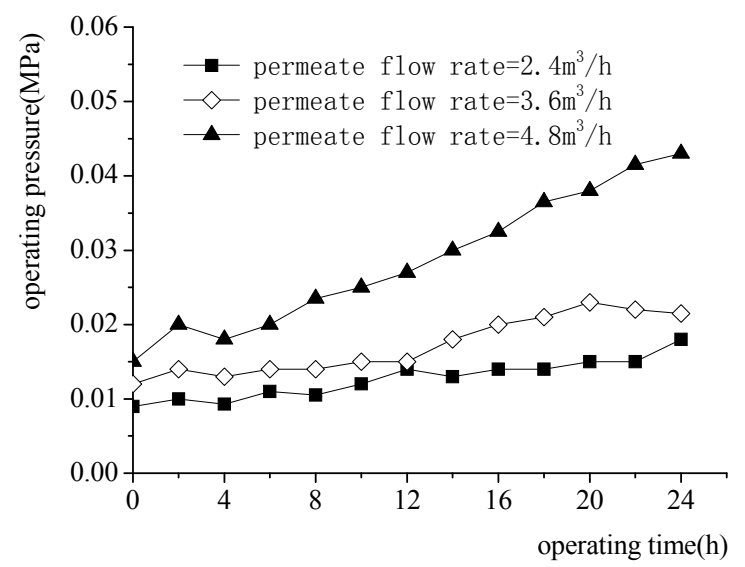

Figure 9. Effect s of permeate flow rate on the UF operating pressure.

$193 \mu \mathrm{g} / \mathrm{L}$ to $179.7 \mu \mathrm{g} / \mathrm{L}$ and $158.7 \mu \mathrm{g} / \mathrm{L}$, respectively, but membranes, especially NF, did not provide adequately high AOC removing efficiency.

The relationship between AOC and MW distribution of organics was also investigated (Figure 8), the result showed that most part of AOC was contributed by low MW organics, which well explained why AOC was so difficult to be removed by membranes.

\subsection{Inorganic Salts Removal by UF-NF System}

Iron and manganese mainly exist in the water along with colloid [9], so they could be rejected by UF, but to other inorganic salts, the rejection of UF was very poor. Most of inorganic salts were rejected by NF (Table 2), the electrical conductivity of NF effluent could be lowered down to less than $100 \mu \mathrm{s} / \mathrm{cm}$.

\subsection{Operation of UF System}

The operating pressure increasement of UF at different permeate flow rate was shown in Figure 9. High permeate flow rate always means rapid accumulation of contaminants on the membrane surface and acceleration of 
Table 2. Inorganic removal by UF-NF system.

\begin{tabular}{|c|c|c|c|}
\hline & raw water & UF effluent & NF effluent \\
\hline Calcium/mg/L & $46.3 \sim 56.7$ & $45.8 \sim 56.2$ & $0.88 \sim 1.25$ \\
\hline magnesium/mg/L & $12.6 \sim 15.7$ & $12.4 \sim 15.3$ & $0.2 \sim 0.6$ \\
\hline sodium/mg/L & $59.4 \sim 67.9$ & $57.6 \sim 66.3$ & $5.44 \sim 7.06$ \\
\hline iron/mg/L & $0.27 \sim 1.28$ & $0.01 \sim 0.12$ & $0.01 \sim 0.03$ \\
\hline manganese/mg/L & $0.13 \sim 0.38$ & $0.01 \sim 0.1$ & $0.001 \sim 0.07$ \\
\hline electrical conductivity/ $\mu \mathrm{s} / \mathrm{cm}$ & $601 \sim 889$ & $622 \sim 750$ & $39 \sim 81$ \\
\hline
\end{tabular}

the membrane fouling [10]. The result indicated that the operating pressure increased slowly when the permeate flow rate was lower than $3.6 \mathrm{~m}^{3} / \mathrm{h}$., but dramatically went up at $4.8 \mathrm{~m}^{3} / \mathrm{h}$.

C. Guigui, et al found that floc produced during coagulation can form a gel cake layer on the surface of

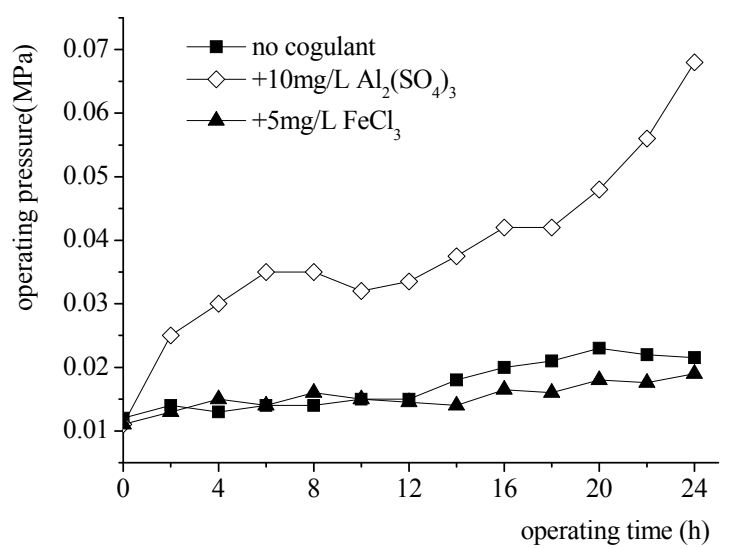

Figure 10. Effects of coagulants addition on the UF operating pressure.

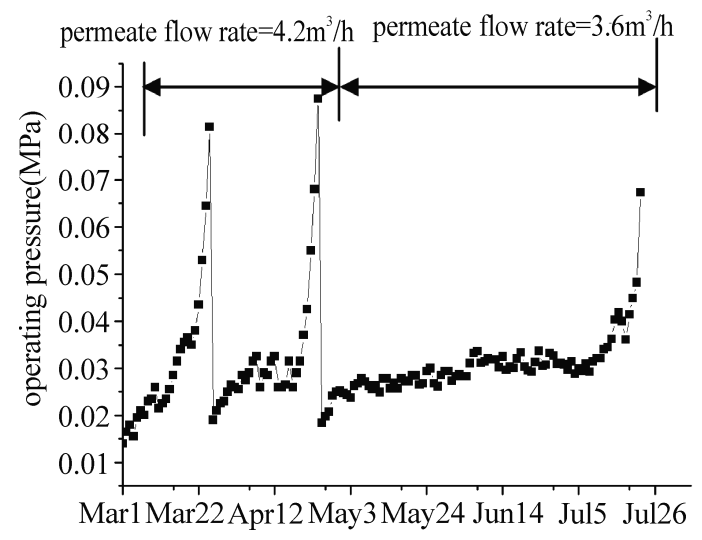

Figure 11. Variety of operating pressure of UF during long time operation.

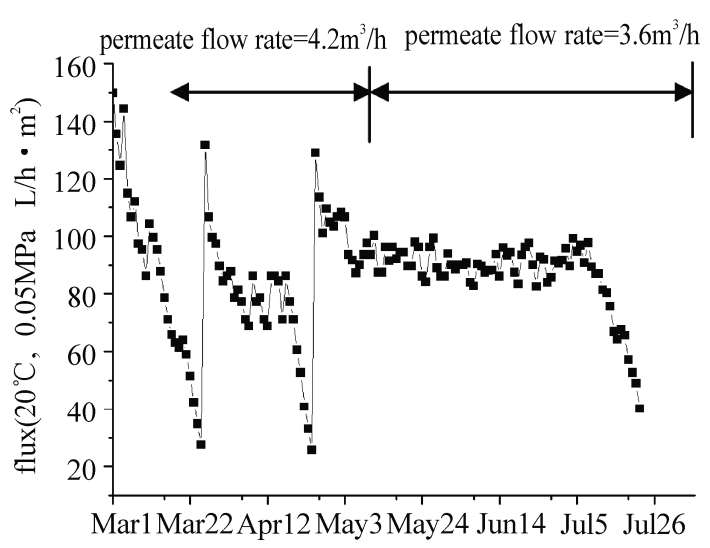

Figure 12. Variety of UF membrane flux during long time operation.

membrane, which may prevent pollutants from contacting with the membrane and slow down the fouling of the membrane [11]. But other researchers found that the dosage of inorganic coagulants may lead to accumulation of salts on membrane surface and accelerate the fouling $[12,13]$.

The results in Figure 10 showed that the addition of $\mathrm{Al}_{2}\left(\mathrm{SO}_{4}\right)_{3}$ or $\mathrm{FeCl}_{3}$ was not favorable to the operation of UF membrane, especially when the alum was dosed before the membrane. The acceleration of the fouling was mainly caused by the interaction between coagulant and PVC alloy, which was confirmed by the supplier of the membrane.

Figure 11 and Figure 12 showed a long-term performance of the UF system when the raw water was directly filtered by the membrane. The initial pressure loss of the clean membrane was less than $0.02 \mathrm{MPa}$ and gradually increased during the course of filtration. In the first 55 days (from March 6 to April 29), the permeate flow rate of UF membrane was kept at $4.5 \mathrm{~m}^{3} / \mathrm{h}$ (permeate flux $=120 \mathrm{~L} / \mathrm{m}^{2} \cdot \mathrm{h}$ ), after $25 \sim 30$ days, the operating pressure climbed up to $0.08 \mathrm{MPa}$, and a chemical cleaning was required. But when the flow rate fell to $3.6 \mathrm{~m}^{3} / \mathrm{h}$ (permeate flux $=90 \mathrm{~L} / \mathrm{m}^{2} \cdot \mathrm{h}$, from April 6 to July 24), the 
chemical cleaning cycle could be prolonged to near 90 days. The performance of the UF system was relatively steady at low permeate flux condition.

When the flux of UF membrane was lower than $30 \mathrm{~L} /$ $\mathrm{m}^{2} \cdot \mathrm{h}$ in March and April, chemical cleaning was carried out. $\mathrm{NaClO}$ was used as cleaning agent in this experiment, after chemical cleaning, more than $90 \%$ of the fouling could be eliminated and the flux could be recovered to about $130 \mathrm{~L} / \mathrm{m}^{2} \cdot \mathrm{h}$.

\subsection{Operation of NF System}

In a 120-day operation (Figure 13), the NF permeate flow rate was maintained at $1.8-2.0 \mathrm{~m}^{3} / \mathrm{h}$ corresponding to a permeate flux at $24-27 \mathrm{~L} / \mathrm{m}^{2} \cdot \mathrm{h}$. The operating pressure was over $0.7 \mathrm{MPa}$ within the first 7 days (in March) when water temperature varied from 13 to $15^{\circ} \mathrm{C}$. With the advent of summer, the operating pressure fell to $0.49 \mathrm{MPa}$ when the water temperature increased to $25-27^{\circ} \mathrm{C}$ in July.

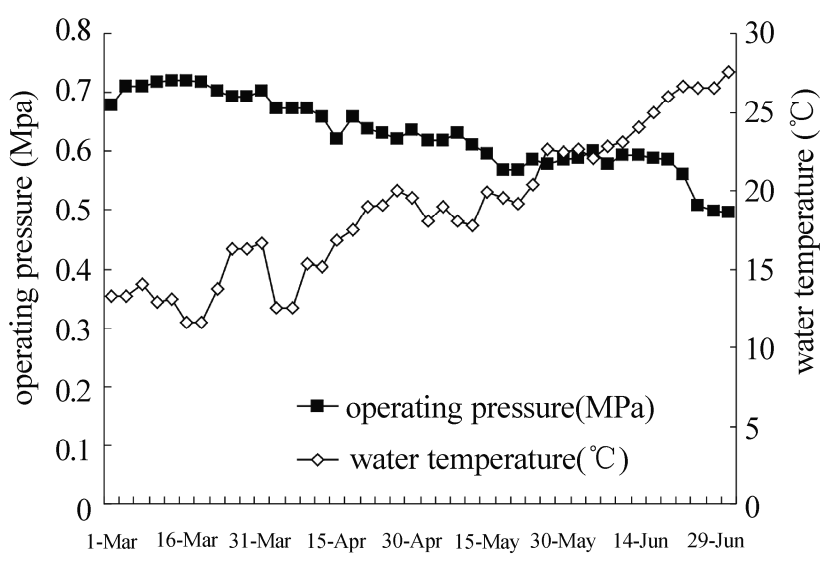

Figure 13. Variety of operating pressure of NF and water temperature during long time operation.

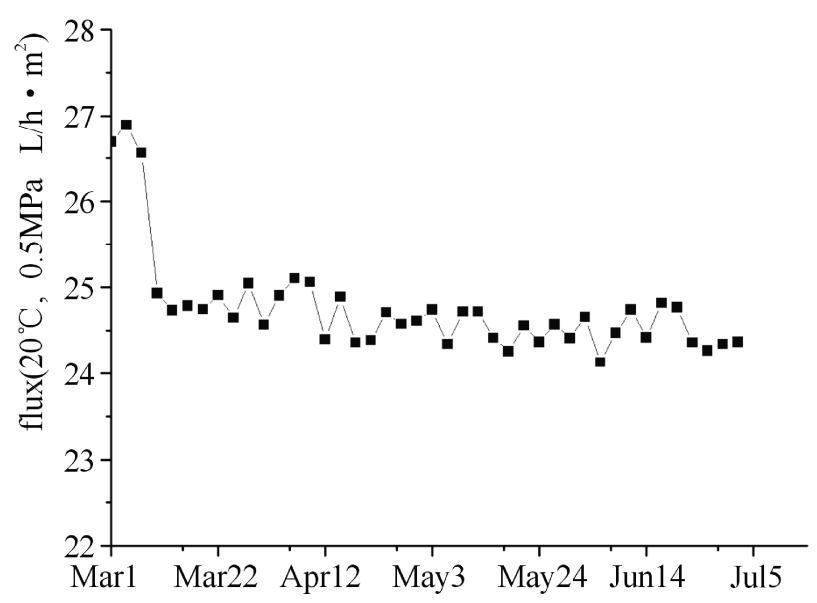

Figure 14. Variety of NF membrane flux during long time operation.
The flux measured at different temperature was corrected to the nominated flux at $25^{\circ} \mathrm{C}$ based on the temperature correction coefficients provided by the membrane manufacturer.(shown in Figure 14), the permeate flux dropped drastically from $27 \mathrm{~L} / \mathrm{m}^{2} \cdot \mathrm{h}$ to $25 \mathrm{~L} / \mathrm{m}^{2} \cdot \mathrm{h}$ in the first 7 days, but after a 120-day continuous operation, the flux was maintained steadily at $24-25 \mathrm{~L} / \mathrm{m}^{2} \cdot \mathrm{h}$, the reduction of NF flux was only $10 \%$ and no chemical clean was required.

\section{Conclusions}

The combined UF-NF process appeared to be a promising technology to remove dissolved organic pollutants from raw water of Huangpu River. UF exhibited an excellent capacity in the respect to reduction of turbidity, iron, manganese, and high MW organics, while NF could further retain relatively low MW organic compounds and inorganic salts. Nevertheless, the UF-NF process showed poor rejection of AOC which was mainly contributed by low MW organic. When the raw water was directly filtered by UF, the UF membrane could operate steadily at a permeate flux of $90 \mathrm{~L} / \mathrm{h} \cdot \mathrm{m}^{2}$, the addition of coagulant (alum or ferric chloride) was ineffective in alleviating the fouling of UF membrane. In a 120-day continuous operation, no serious fouling was observed in NF membrane, the flux was maintained steadily at $24-25 \mathrm{~L} / \mathrm{m}^{2} \cdot \mathrm{h}$.

\section{Acknowledgment}

This research was supported by Shanghai Municipal Engineering Design General Institute and Shanghai Minhang Water supply Co. Ltd.

\section{References}

[1] Y. Magara, S. Kunikane, and M. Itoh, "Advanced membrane technology for application to water treatment," Wat Sci Tech, Vol. 37, pp. 91-99, October 1998.

[2] AWWA Membrane technology research committee, "Committee report: Membrane process," JAWWA, Vol. 90, pp. 91-105, June 1998.

[3] S. Kunikane, M. lton, and Y. Magara, "Advanced membrane technology of application to water treatment," Water Supply, Vol. 16, pp. 313-318, January 1998.

[4] Amy, L. Gary, Collins, R. Michael, Kuo, C. James, King, and H. Paul, "Comparing gel permeation chromatography and ultrafiltration for the molecular weight characterization of aquatic organic matter," J. AWWA, Vol. 79, pp. 43-39, January 1987.

[5] W. Liu, H. Wu, Z. Wang, S. L. Ong, J. Y. Hu and W. J. $\mathrm{Ng}$, "Investigation of assimilable organic carbon (AOC) and bacterial regrowth in drinking water distribution system,” Water Research, Vol. 36, pp. 891-898. February 2002. 
[6] D. Van der Kooij, W. A. M. Hijnen, and A. Visser, "Determining the concentration of easily assimilable organic carbon in drinking water," J. AWWA, Vol. 74, pp. 540-545, October 1982.

[7] P. M. Huck, "Measurement of biodegradable organic matter and bacterial growth potential in drinking water," J. AWWA, Vol. 82, pp. 78-86, July 1990.

[8] N. Park, B. Kwon, M. Sun, H. Ahn, C. Kim, C. Kwoak, D. Lee, S. Chae, H. Hyung, and J. Cho, "Application of various membranes to remove NOM typically occurring in Korea with respect to DBP, AOC and transport parameters," Desalination, Vol. 178, pp. 161-169, July 2005.

[9] C. Cabassud, C. Anselme, and J. J. Bersillon, "Ultrafiltration as a non-polluting alternative to traditional clarification in water treatment," Filtration \&separation, Vol. 28, pp.194-198, July 1999.
[10] Z. Wang, J. M. Yao, C. Zhou and J. S Chu, "The influence of various operating conditions on the permeation flux during dead-end microfiltration," Desalination, Vol. 212, pp. 209-218, June 2007.

[11] C. Guigui, J. C. Rouch, L. Durand-Bourlier, V. Bonnelye and P. Aptel, "Impact of coagulation conditions on the in-line coagulation/UF process for drinking water production," Desalination, Vol. 147, pp. 95-100, September 2002.

[12] L. T. Veornique, R. W. Mark, J. Y. Bottero et al, "Coagulation pretreatment for ultrafiltration of a surface water, JAWWA, Vol. 82, pp. 76-81, December 1990.

[13] K. Khatib, J. Rose, O. Barres, W. Stone, J. Y. Bottero, and C. Anselme, "Physico-chemical study of fouling membrane mechanisms of ultrafiltration membrane on Biwa Lake(Japan)," Jour Membrane Science, Vol. 130, pp. $53-62$, July 1997. 